Creative Commons User License: CC BY-NC-ND

Abstracted by: EBSCOhost, Electronic Journals Service (EJS), Google Scholar, Journal Seek, Scientific Commons,

Food and Agricultural Organization (FAO), CABI and Scopus

http://eoi.citefactor.org/10.11226/v25i4
Journal of Agricultural Extension

Vol. 25 (4) October, 2021

ISSN(e): 24086851; ISSN(Print); 1119944X

http://journal.aesonnigeria.org

http://www.ajol.info/index.php/iae

Email: editorinchief@aesonnigeria.org

\title{
Determinants of Inorganic Fertilizer Use by Smallholder Farmers in South Wollo and Oromia Special Administrative Zones, Ethiopia
}

https://dx.doi.org/10.4314/jae.v25i4.11

\section{Adisalem, Samuel Tadesse}

Department of Rural Development and Agricultural Extension, Wollo University, P.O. Box. 1145, Dessie Ethiopia.Addissami2127@gmail.com; +251922610001

\section{Dinku, Amare Molla}

Department of Rural Development and Agricultural Extension, Wollo University, P.O. Box. 1145, Dessie Ethiopia. amare.dinku@wu.edu.et or amare0399@gmail.com $+251912851997$

\section{Abstract}

The study investigated the determinants of fertilizer use by smallholder farmers. Data were drawn from 207 smallholder farmers, experts, and respective office heads using structured and semi-structured interview schedules, Key informant interviews and focus group discussions. Data were analysed using percentage, mean and standard deviation and linear regression model. About $94 \%$ of the farmers had the willingness to apply inorganic fertilizer on their farmland. An increasing price of inorganic fertilizer (96\%), poor demand estimation (82\%), delay in distribution (78\%), lack of attention for the irrigation production system (65\%), and unfair distribution/nepotism (61\%) are the top-ranked challenges affecting inorganic fertilizer use. The existence of more active labour forces in the family $(d y / d x=20.4, t=2.49)$,farmsize ( $d y / d x=14.53, t=3.82)$, oownership( $d y / d x=75$ $.13, t=10.64)$, total income ( $d y / d x=0.00024, t=2.24)$, use of credit service $(d y / d x=31.11, t=1.94)$, and frequency of extension contact $(d y / d x=24.60, t=2.07)$, were found significantly promoting the amount of fertilizer use by smallholder farmers. Actions such as real demand estimation, arranging agricultural implements, and fertilizer subsidy for resource-poor farmers should be implemented to ensure food self-sufficiency.

Key words: Determinants, smallholder farmers, inorganic fertilizer, use, Ethiopia

\section{Introduction}

Agriculture is the main livelihood source of smallholder farmers who live in the developing world with the domination of traditional farming practices (Andani et al., 2020; Rehman et. al., 2019). However, soil infertility is the major cause of food insecurity and poverty in developing countries and it invites to the use of chemical fertilizer (Martey et al., 2019). In sub-Saharan African countries, low fertility and inefficient management of soil is the main challenge facing productivity among smallholder farmers (Raimi et al., 2017). An increase in the amount of inorganic fertilizer is essential to restore and maintain soil fertility in Sub-Saharan countries (Andani et al., 2020; Van and Grogan, 2020). Similarly, inorganic fertilizer is crop yield-enhancing technology for improving smallholder farmers' income and food security by enhancing land productivity (Andani et al. 2020). In contrast, scholars argue that the use of inorganic fertilizer can contribute to greenhouse gas emissions 
Creative Commons User License: CC BY-NC-ND

Abstracted by: EBSCOhost, Electronic Journals Service (EJS), Google Scholar, Journal Seek, Scientific Commons,

Food and Agricultural Organization (FAO), CABI and Scopus
Journal of Agricultural Extension

Vol. 25 (4) October, 2021

ISSN(e): 24086851; ISSN(Print); 1119944X

http://journal.aesonnigeria.org

http://www.ajol.info/index.php/jae

Email: editorinchief@aesonnigeria.org

though it has become an essential part of our global food supply chain (Walling and Vaneeckhaute, 2020). Similarly, the continued use of chemical fertilizer poses serious collateral problems such as environmental pollution, pest resistance development and food safety decline (Singh et al., 2016, Ye et al, 2020; Pandey and Diwan, 2021). Other studies revealed the advantage of using organic fertilizer over chemical fertilizer, at least an integral use of both organic and inorganic fertilizer, to ensure adequate supply of plant nutrients and sustain maximum crop yield and profitability for environmentally sustainable soil productivity (Abdulraheem et al, 2018; Adane et al., 2020). In the context of environmental sustainability, using organic instead of chemical fertilizer is the new inevitable future of agricultural production (Raimi et al., 2017; Yang et al., 2020). However, the basic question is that maximizing food production for feeding a rapidly growing human population while minimizing soil quality degradation is a major challenge for global sustainability (Sarkar et al., 2020).

With the rapid population growth, food production hinges largely upon access to fertilizer (Powers et al., 2017). The effective use of inorganic fertilizer becomes very essential to boost land productivity and achieve food security with the growing world population which is expected to reach 9.7 billion by 2050, within arable land scarcity which will increase the current demand for food by $70 \%$ (Randive et al., 2021). There is an increased demand for agricultural products since the world population is doubled in the past decades and the situation is more severe in sub-Saharan African Countries (Shanka, 2020). Similarly, the imbalance between the population growth rate and the agricultural production growth rate is one of the prominent national problems in Ethiopia (Abebe \& Debebe, 2020). The rapid population growth in Ethiopia is aggravating farmland scarcity especially for youths and creates a high demand for food and non-food items (Legesse et al., 2019). Increasing inorganic fertilizer application allows farmers to gain better welfare (Legesse et al., 2019). Even the non-farming communities can enjoy a lower cost of food items as being a net consumer in today's inflated market. Recent studies indicated a strong relationship between yield and fertilizer use among smallholder farmers (Pandey and Diwan, 2021). Similarly, enhancing agricultural production to feed the ever-growing population requires the rational use of inorganic fertilizer (Noor et al., 2020; Nyamangara et al., 2020).

Despite its importance, farmers are still applying inorganic fertilizer lower than the recommended rate and some of the farmers do not apply at all in the study area as the use of inorganic fertilizer is generally low in developing countries because of smallholder farmers' low purchasing power and access to the inorganic fertilizer (Nyamangara et al., 2020). Several studies have identified factors affecting fertilizer adoption, but the factors vary from place to place and time to time (Ketema and Kebede, 2017). Thus, an area specific study is required to explain the determinants of inorganic fertilizer use. This study analysed the willingness, challenges and determinants of fertilizer use by smallholder farmers 
Creative Commons User License: CC BY-NC-ND

Abstracted by: EBSCOhost, Electronic Journals Service (EJS),

Google Scholar, Journal Seek, Scientific Commons,

Food and Agricultural Organization (FAO), CABI and Scopus
Journal of Agricultural Extension

Vol. 25 (4) October, 2021

ISSN(e): 24086851; ISSN(Print); 1119944X

http://journal.aesonnigeria.org

http://www.ajol.info/index.php/jae

Email: editorinchief@aesonnigeria.org

\section{Methodology}

South Wollo and Oromia special administrative zones are found in the eastern Amhara Region of Ethiopia. South Wollo Zone is $404 \mathrm{Km}$ far from Addis Ababa, the capital of Ethiopia, in the north. It is located between the Latitude of $10.8997^{\circ}$ north and Longitude $38.9877^{\circ}$ east with three agro-ecologies; lowland, midland and highland. The annual rainfall ranges from $750-1400 \mathrm{~mm}$ with a long-term mean of $1109 \mathrm{~mm}$. On the other hand, Oromia special administrative zone is $333 \mathrm{Km}$ far from Addis Ababa in the north. It is located between the Latitude $10^{\circ} 42^{\prime} 59.99^{\prime \prime}$ north and Longitude $39^{\circ} 51^{\prime}$ 59.99" east. The Zone is bordered on the southwest by North Shewa Zone, on the northwest by South Wollo and Argobba special woreda, and on the east by the Afar Region. The main agro-ecologies of the zone are low land and midland with an annual rainfall range of $600-900 \mathrm{~mm}$.

Multi-stage sampling procedure was used to draw respondents. Three districts, Jamma, Tehuledere (from South Wollo Zone), and Dawachefa (from Oromia special administrative Zone) were selected randomly. Then, six kebeles were selected from the three districts randomly. Finally, 207 sample smallholder farmers were drawn from the fresh list of sample frame using systematic random sampling.

Both qualitative and quantitative data were collected using a pre-tested interview schedule with the help of an ODK data Kit. Willingness of small holder farmers to apply inorganic fertilizer on their farmland, and the main challenges to access to inorganic fertilizer that can influence inorganic fertilizer use patterns were gathered. Focus group discussion (FGD) and key informant interviews were conducted with stakeholders.

The research followed descriptive and econometric analysis, multiple linear regressions approach. The econometric model specification of the variables is explained as follows.

$$
\mathrm{Yi}=\mathrm{B} 0+\mathrm{B} 1 \mathrm{X} 1+\mathrm{B} 2 \mathrm{X} 2+\mathrm{B} 3 \mathrm{X} 3+\mathrm{B} 4 \mathrm{X} 4+\mathrm{B} 5 \mathrm{X} 5 \ldots+\mathrm{B} 13 \mathrm{X} 13
$$

Where: $\mathrm{B}_{0}=$ is the intercept; $\mathrm{B}_{1}, \mathrm{~B} 2 \ldots \mathrm{B} 13$, are coefficients

$$
\begin{aligned}
& \mathrm{Yi}=\text { Quantity of fertilizer used by } \\
& \text { smallholder farmers; } \quad \mathrm{X}_{1} ; \mathrm{X}_{13}=
\end{aligned}
$$

Explanatory variables

Variance inflation factor (VIF) and ccontingency ccoefficient tests were employed to check Multicollinearity problem among the continuous and dummy explanatory variables respectively and there were no collinearity problem.

\section{Results and Discussion}

\section{Willingness of Stallholder Farmers to Apply Inorganic Fertilizer}

About $94 \%$ of the respondents are willing to apply inorganic fertilizer on their farm land. This implies that the use of inorganic fertilizer can boost plot level productivity with the small plot of land and fast-growing population. The current study revealed that there is an increasing pattern of using inorganic fertilizer among small holder farmers to boost farm productivity (Tesfay, 2021). 
Creative Commons User License: CC BY-NC-ND

Abstracted by: EBSCOhost, Electronic Journals Service (EJS), Google Scholar, Journal Seek, Scientific Commons,

Food and Agricultural Organization (FAO), CABI and Scopus
Journal of Agricultural Extension

Vol. 25 (4) October, 2021

ISSN(e): 24086851; ISSN(Print); 1119944X

http://journal.aesonnigeria.org

http://www.ajol.info/index.php/jae

Email: editorinchief@aesonnigeria.org

However, there are many challenges in the supply and distribution system which farmers faced to use of inorganic fertilizer. The main challenges farmers face in access to inorganic fertilizers are high price of fertilizers, infrastructure problem like road facility, late delivery, unavailability of credit facility, and no appropriate storage facility in farmers' association offices which make fertilizers liable for theft and spoilage. The current distribution system of inorganic fertilizer is linked with a local credit institution, but not with the issue of access to credit service for smallholder farmers. The low consumption of inorganic fertilizer was explained by limited access to credit in the study area as it has been explained by the focus group discussants. The other main challenge in fertilizer consumption is the activities of illegal private fertilizer providers. A significant number of farmers buy inorganic fertilizer from local markets and neighbouring farmers. These in turn lead farmers to use low-quality fertilizer. This problem was high in the Tehuledere district. Farmers explained the reason that there was no affordable quantity to be supplied by the cooperatives below $50 \mathrm{Kg}$ as per the demand of farmers. As a result, farmers prefer the local market since they can buy the amount they need. The respondents identified and ranked the major challenges of smallholder farmers' access to inorganic fertilizer inorganic fertilizer price increment was the most felt challenge in the study area, followed by poor demand estimation and delay in distribution of inorganic fertilizer. This implies that smallholder farmers are more sensitive to price fluctuation in the market, and it influences the use of inorganic fertilizer (Shee et al., 2020)

Table 1: Major challenges to access inorganic fertilizer Challenges to access inorganic fertilizer

High price of inorganic fertilizer

Poor demand estimation of inorganic fertilizer

Delay in distribution of inorganic fertilizer Percentage $(\mathbf{n}=207)$

Difficult to access in the right mix at the same time 96

Lack of attention for Irrigation production system 82

Unfair distribution/nepotism 78

Low performance of the supply and distribution system

69

Difficult to access right quantity of inorganic fertilizer

Difficult to access right quality of inorganic fertilizer

No legal private agro-dealers

Lack of appropriate fertilizer storage facility

Source: Survey, 2020

\section{Determinants of Inorganic Fertilizer Use}

Active labour forces in the family: Higher number of active family labour force leads to decisions to take the risk of participation in technology packages, and hence the family labour force contributes to use of inorganic fertilizer. The rate of inorganic fertilizer consumption is positively influenced by the number of man equivalent present in the household. The result shows that as the number of active labour force of the family increases by 1 unit, fertilizer utilization of the family would increase by $20.4 \mathrm{Kg}$. This implies that fertilizer utilization needs a high labour force, and this idea was raised during the focus group discussion. Moreover, when the number of active 
Creative Commons User License: CC BY-NC-ND

Abstracted by: EBSCOhost, Electronic Journals Service (EJS), Google Scholar, Journal Seek, Scientific Commons,

Food and Agricultural Organization (FAO), CABI and Scopus
Journal of Agricultural Extension

Vol. 25 (4) October, 2021

ISSN(e): 24086851; ISSN(Print); 1119944X

http://journal.aesonnigeria.org

http://www.ajol.info/index.php/jae

Email: editorinchief@aesonnigeria.org

labour force of the family increases, taking the risk of using production enhancing inputs would increase. This result coincides with the findings of Tamirat, (2020).

Farm Size: Farm size influenced positively inorganic fertilizer consumption. The marginal effect indicates that if other things remaining constant, the amount of fertilizer utilization increases by $14.53 \%$ as an additional unit (Timad) of land increases by one unit. Therefore, farm size is an important variable in the inputoutput marketing participation and fertilizer consumption. The result is in line with the findings of Bai et al., (2019), Ambaw (2019), Martey et al., (2019), and Pandey and Diwan, (2021).

Income of the household: Its coefficient came out to be positive and statistically significant. The marginal effect indicates that other things remaining constant, the amount of fertilizer utilization increases by $0.025 \%$ as the income of the household increases by one percent. This implies that households who have access to better income opportunities are likely to use more fertilizer than those households who had no or little access. The possible reason might be that income of the household determines the purchasing power of households since fertilizer is distributed on a cash basis. Moreover, households that have low income suffer more from an increasing fertilizer price. The result is in line with the findings of prior studies Ambaw, (2019).

Oxen Ownership: It was found that having more oxen positively and significantly influences smallholder farmers' use of inorganic fertilizer. The marginal effect indicates that, other things remaining constant, the amount of fertilizer utilization increases by $75.13 \%$ as the household owns one extra ox. The possible explanation could be that households with more oxen have better drought power and financial position to purchase and apply sufficient amount of inorganic fertilizer inputs. Ox ownership is a very crucial variable especially during the peak sowing time, June and July in the case of the study area, to use inorganic fertilizer. The finding is in line with that of Ketema and Kebede (2017) and Silva et al., (2019) with the explanation stated that farmers with more oxen applied more fertilizer to maize production in Hawassa, Ethiopia.

Use of credit: The result of the model depicted that the use of credit service has a positive relationship with the consumption of inorganic fertilizer by smallholder farming households. Other things being unchanged, the probability of using more amounts of inorganic fertilizer increases by $31.11 \%$ for households who use credit services compared to households who do not use credit services. This implies that credit can buffer the financial constraints of farmers to buy inorganic fertilizer. This finding is similar to others' findings with the explanation that farmers' financial condition and purchasing capacity are crucial in deciding about the amount of fertilizer to be consumed (Pandey and Diwan, 2021).

Extension contact: Frequency of extension workers' contact with farmers observed to have a positive influence on the use of inorganic fertilizer. It was shown that an increase in one contact increases the amount of fertilizer consumption by $24.60 \mathrm{Kg}$. Farmers who get more contact with frontline extension workers are able to receive better information and advice for agricultural technology information including fertilizer (Gebreegziabher and Mezgebo, 2020). Access to extension service is the main determinant factor to apply agricultural technologies (Usman et al., 2020). This 
Creative Commons User License: CC BY-NC-ND

Abstracted by: EBSCOhost, Electronic Journals Service (EJS),

Google Scholar, Journal Seek, Scientific Commons,

Food and Agricultural Organization (FAO), CABI and Scopus

http://eoi.citefactor.org/10.11226/v25i4
Journal of Agricultural Extension

Vol. 25 (4) October, 2021

ISSN(e): 24086851; ISSN(Print); 1119944X

http://journal.aesonnigeria.org

http://www.ajol.info/index.php/jae

Email: editorinchief@aesonnigeria.org

implies that farmers who have a high frequency of contact can take the advantage of taking information and use more fertilizer. The finding is congruent with the result of Ambaw (2019).

Table 2. Determinants of inorganic fertilizer use

\begin{tabular}{lllll}
\hline Variables & Coefficients & S.E & $T$ & Marginal effect \\
\hline Age (in years) & -.2638208 & .5557234 & -0.47 & -.2638208 \\
Sex & 3.014735 & 20.70755 & 0.15 & 3.014735 \\
Education level & 23.58443 & 17.01282 & 1.39 & 23.58443 \\
Active family labour & $20.40004^{* * *}$ & 8.18719 & $2.49^{*}$ & 20.40004 \\
Family size & $-6.17477^{* *}$ & 4.642543 & 1.33 & -6.17477 \\
Farm size & $14.53246^{* *}$ & 3.805877 & $3.82^{*}$ & 14.53246 \\
Income & $.000247^{* *}$ & .0001104 & 2.24 & .000247 \\
Number of Oxen & $75.13703^{* * *}$ & 7.061817 & $10.64^{*}$ & 75.13703 \\
Training & 4.780289 & 5.143729 & 0.93 & 4.780289 \\
use of Credit & $31.1132^{* *}$ & 16.06708 & 1.94 & 31.1132 \\
Market distance & .0165534 & .2501801 & 0.07 & .0165534 \\
Extension contact & $24.60037^{* *}$ & 11.89746 & 2.07 & 24.60037 \\
Use of irrigation & 18.44479 & 15.70916 & 1.17 & 18.44479 \\
-Constant & $-105.585^{* *}$ & 43.66287 & 2.42 & \\
\hline PSO.05 & & & &
\end{tabular}

${ }^{*} \mathrm{P} \leq 0.05$

$\begin{array}{ll}\text { R-squared } & 0.6064 \\ \text { Adj R-squared } & 0.5799 \\ \text { Root MSE } & 98.945 \\ \text { Prob > F } & 0.0000 \\ \text { Observation } & 207\end{array}$

Source: Survey, 2020

\section{Conclusion and Recommendations}

There is an increasing inorganic fertilizer consumption by smallholder farmers. Smallholder farmers' access to inorganic fertilizer is challenged by increasing price of inorganic fertilizer, poor demand estimation, delay in distribution of inorganic fertilizer, difficulty in getting the types and amount of inorganic fertilizer at the right time, and lack of attention for Irrigation production system are the top-ranked challenges. On the other hand, the existence of more active labour forces in the family, farm size, having oxen, total income, use of credit service and frequency of extension contact were found to significantly promote the consumption of inorganic fertilizer by smallholder farmers.

Government and other development partners should focus on the supply and distribution side of inorganic fertilizer through enhancing real demand estimation, finding a financial solution for resource-poor farmers and motivating frontline extension workers for better contact. The introduction of labour-saving farm tools is very critical to enhance inorganic fertilizer application to support households with low active labour force and with low number of / having no ox.

Competing interests: The authors declare that there is no competing interest. 
Creative Commons User License: CC BY-NC-ND

Abstracted by: EBSCOhost, Electronic Journals Service (EJS),

Google Scholar, Journal Seek, Scientific Commons,

Food and Agricultural Organization (FAO), CABI and Scopus
Journal of Agricultural Extension

Vol. 25 (4) October, 2021

ISSN(e): 24086851; ISSN(Print); 1119944X

http://journal.aesonnigeria.org

http://www.ajol.info/index.php/iae

Email: editorinchief@aesonnigeria.org

\section{Acknowledgement}

We would like to thank Wollo University for funding the data collection and analysis.

Reference

Abdulraheem, M. I., Charles, E. F., Moshood, A. Y., \& Omogoye, A. M. (2018). Comparative performance of different varieties of maize under organic, inorganic and combined (Organic and Inorganic) fertilization. Agricultural Studies International Technology and Science Publications, 2(2), 20-29.

Abebe, G., \& Debebe, S. (2020). Determinants of recommended agronomic practices adoption among wheat producing smallholder farmers in Sekela District of West Gojjam Zone, Ethiopia. Journal of Development and aAgricultural Economics, 12(1), 17-24.

Adane, M., Misganaw, A., \&Alamnie, G. (2020). Effect of Combined Organic and Inorganic Fertilizer on Yield and Yield Components of Food Barley (Hordeum Vulgare L.).

Ambaw, Y. D. (2019). Analysis of factors affecting the demand for inorganic fertilizer in Boricha and Wondogenet Districts, Southern Ethiopia. African Journal of Agricultural Research, 14(10), 609-616.

Andani, A., Moro, A. H. B., \&lssahaku, G. (2020). Fertilizer subsidy policy and smallholder farmers crop productivity: The case of maize production in North-Eastern Ghana. Journal of Agricultural Extension and Rural Development, 12(2), 18-25.

Bai, X., Wang, Y., Huo, X., Salim, R., Bloch, H., \& Zhang, H. (2019). Assessing fertilizer use efficiency and its determinants for apple production in China. Ecological Indicators, 104, 268-278.

Gebreegziabher, K. T., \& Mezgebo, G. K. (2020). Smallholder farmers willingness to pay for privatized agricultural extension services in Tigray National Regional State, Ethiopia. Journal of Agricultural Extension, 24(4), 29-38.

Ketema, M., \& Kebede, D. (2017). Adoption intensity of inorganic fertilizers in maize production: empirical evidence from smallholder farmers in eastern Ethiopia. Journal of Agricultural Science, 9(5), 124-132.

Legesse, E. E., Srivastava, A. K., Kuhn, A., \& Gaiser, T. (2019). Household Welfare Implications of Better Fertilizer Access and Lower Use Inefficiency: Long-Term Scenarios for Ethiopia. Sustainability, 11(14), 3952.

Martey, E., Kuwornu, J. K., \&Adjebeng-Danquah, J. (2019). Estimating the effect of mineral fertilizer use on Land productivity and income: Evidence from Ghana. Land Use Policy, 85, 463-475.

Noor, M. A., Nawaz, M. M., ul Hassan, M., Sher, A., Shah, T., Abrar, M. M., ... \& Ma, W. (2020). Small farmers and sustainable N and P management: Implications and potential under changing climate. In Carbon and Nitrogen Cycling in Soil (pp. 185219). Springer, Singapore.

Nyamangara, J., Kodzwa, J., Masvaya, E. N., \&Soropa, G. (2020). The role of synthetic fertilizers in enhancing ecosystem services in crop production systems in developing countries. In The role of ecosystem services in sustainable food systems (pp. 95117). Academic Press.

Pandey, C., \& Diwan, H. (2021). Assessing fertilizer use behaviour for environmental management and sustainability: a quantitative study in agriculturally intensive regions of Uttar Pradesh, India. Environment, Development and Sustainability, 23(4), 58225845.

Powers, S. M., Chowdhury, R. B., MacDonald, G. K., Metson, G. S., Beusen, A. H. W., Bouwman, A. F., ... \& Vaccari, D. A. (2019). Global opportunities to increase 
Creative Commons User License: CC BY-NC-ND

Abstracted by: EBSCOhost, Electronic Journals Service (EJS),

Google Scholar, Journal Seek, Scientific Commons,

Food and Agricultural Organization (FAO), CABI and Scopus
Journal of Agricultural Extension

Vol. 25 (4) October, 2021

ISSN(e): 24086851; ISSN(Print); 1119944X

http://journal.aesonnigeria.org

http://www.ajol.info/index.php/jae

Email: editorinchief@aesonnigeria.org

http://eoi.citefactor.org/10.11226/v25i4

agricultural independence through phosphorus recycling. Earth's Future, 7(4), 370383.

Raimi, A., Adeleke, R., \& Roopnarain, A. (2017). Soil fertility challenges and Biofertiliser as a viable alternative for increasing smallholder farmer crop productivity in sub-Saharan Africa. Cogent Food \& Agriculture, 3(1), 1400933.

Randive, K., Raut, T., \&Jawadand, S. (2021). An overview of the global fertilizer trends and India's position in 2020. Mineral Economics, 1-14.

Rehman, A., Chandio, A. A., Hussain, I., \& Jingdong, L. (2019). Fertilizer consumption, water availability and credit distribution: major factors affecting agricultural productivity in Pakistan. Journal of the Saudi Society of Agricultural Sciences, 18(3), 269-274.

Sarkar, D., Kar, S. K., Chattopadhyay, A., Rakshit, A., Tripathi, V. K., Dubey, P. K., \& Abhilash, P. C. (2020). Low input sustainable agriculture: a viable climate-smart option for boosting food production in a warming world. Ecological Indicators, 115, 106412.

Shanka, D. (2020). Roles of eco-friendly low input technologies in crop production in subSaharan Africa. Cogent Food \& Agriculture, 6(1), 1843882.

Shee, A., Azzarri, C., \& Haile, B. (2020). Farmers' willingness to pay for improved agricultural technologies: Evidence from a field experiment in Tanzania. Sustainability, 12(1), 216.

Silva, J. V., Baudron, F., Reidsma, P., \& Giller, K. E. (2019). Is labour a major determinant of yield gaps in sub-Saharan Africa? A study of cereal-based production systems in Southern Ethiopia. Agricultural Systems, 174, 39-51.

Singh, M., Dotaniya, M. L., Mishra, A., Dotaniya, C. K., Regar, K. L., \& Lata, M. (2016). Role of biofertilizers in conservation agriculture. In Conservation Agriculture (pp. 113-134). Springer, Singapore.

Tamirat, N.(2020) Adoption of Chemical Fertilizer Technology and Household Food Security, in Southern Ethiopia, in Case of Soro District in Hadiya Zone.

Tesfay, M. G. (2021). The impact of participation in rural credit program on adoption of inorganic fertilizer: A panel data evidence from Northern Ethiopia. Cogent Food \& Agriculture, 7(1), 1919388.

Usman, Z. O., Olagunju, K. O., \&Ogunpaimo, O. R. (2020). Determinants of adoption of multiple sustainable agricultural practices among smallholder farmers in Nigeria. International Soil and Water Conservation Research.

Van Asselt, J., \& Grogan, K. A. (2020). Do Fertilizer Subsidies Improve Soil Quality: Myopic vs. Dynamic Analysis of Smallholder Farmers in Ghana.

Walling, E., \&Vaneeckhaute, C. (2020). Greenhouse gas emissions from inorganic and organic fertilizer production and use: A review of emission factors and their variability. Journal of Environmental Management, 276, 111211.

Yang, Y., He, Y., \& Li, Z. (2020). Social capital and the use of organic fertilizer: an empirical analysis of Hubei Province in China. Environmental Science and Pollution Research, 1-12.

Ye, L., Zhao, X., Bao, E., Li, J., Zou, Z., \& Cao, K. (2020). Bio-organic fertilizer with reduced rates of chemical fertilization improves soil fertility and enhances tomato yield and quality. Scientific reports, 10(1), 1-11. 